\title{
EMANCIPAÇÃO E SUA PROBLEMÁTICA TRAJETÓRIA CONCEITUAL
}

\section{EMANCIPATION AND ITS PROBLEMATIC CONCEPTUAL TRAJECTORY}

\author{
Matheus Maria Beltrame* \\ Edmilson Alves de Azevêdo** \\ Recebido: 05/2017 \\ Aprovado:08/2017
}

\begin{abstract}
Resumo: o artigo traz um recorte da tese A teoria emancipação em Karl Marx e Jürgen Habermas ${ }^{1}$. Nosso objetivo, nesse trabalho, é o de analisar o desenvolvimento históricoconceitual de emancipação a partir dos elementos que o fundamentam: o humanismo, o Iluminismo, a ciência e tecnologia, a metafísica, a antropologia filosófica e a filosofia da história. Trata-se de um estado da arte do conceito de emancipação a partir da metodologia história dos conceitos que analisa o desenvolvimento desse conceito desde a sua origem no direito romano se estendendo a Idade Média e Idade Moderna.
\end{abstract}

Palavras-chave: Emancipação. Iluminismo. Humanismo. Ciência. Filosofia da História.

\begin{abstract}
Karl Marx and Jürgen Habermas. Our objective in this work is to analyze the historical-conceptual development of emancipation from the elements that underlie it: humanism, Enlightenment, science and technology, metaphysics, philosophical anthropology and philosophy of history. It is a state of the art concept of emancipation from the methodology history of concepts that analyzes the development of this concept from its origin in Roman law extending the Middle Ages and Modern Age.
\end{abstract}

Keywords: Emancipation. Enlightenment. Humanism. Science. Philosophy of History.

\section{Introdução}

Neste artigo discute-se o conceito de emancipação em seu desenvolvimento histórico-conceitual no léxico político e jurídico da tradição ocidental. Em seu percurso conceitual mostra-se originariamente como um termo que tem sua origem na tradição do Direito Romano, estendendo-se ao período medieval, com seu apogeu na Idade Moderna, ao mesmo tempo em que mantém esta característica jurídica e será profundamente ressignificado no século XVIII, no movimento iluminista, com a compreensão da necessidade de emancipação do "indivíduo" e o surgimento desta categoria sócio-histórica no processo civilizatório ocidental (ELIAS,1993).

No lluminismo a emancipação vem ser compreendida com o sentido à de autoemancipação. Destarte, entre as premissas naturais, a auto-habilitação individual ou coletiva e a normalização jurídica, ela vai adquirir uma nova qualidade histórica. Este conceito será interpretado, simultaneamente, em sentido normativo e autorreflexivo, da sequência da evolução histórica.

Apresentamos o desenvolvimento histórico conceitual da noção e os

\footnotetext{
* Dr. em Filosofia pela UFPB. Mestre em Filosofia pela UNIOESTE. Licenciado em Filosofia Plena pela UNOCHAPECÓ. Professor Substituto na UEPB.

** Professor Titular na UFPB. Membro do Programa Integrado de Pós-Graduação em Filosofia PIPF/UFPB-UFPE-UFRN. Coordenador do Grupo Hermes de Pesquisa.

Problemata: R. Intern. Fil. V. 8. n. 2 (2017), p. 72-103 ISSN 2236-8612 doi:http://dx.doi.org/10.7443/problemata.v8i2.35880
} 
elementos que constituem sua a problemática e fundamento semântico. Tratase de buscar fixar aqueles elementos que contextualiza a problemática da emancipação a partir das teorias que a constituem. De partida, identificam-se aspectos derivados da tradição humanista, bem como da visão de mundo iluminista, Aborda-se ainda elementos da filosofia da história, da Antropologia Filosófica, da metafísica, das ciências e tecnologia presentes e nas discussões em torno deste conceito.

\section{Desenvolvimento histórico conceitual}

O conceito de emancipação originou-se no Direito Romano, tendo continuidade no período medieval, terminando por se consolidar na tradição do Iluminismo com essa característica jurídica. Esse conceito, independentemente das formas de governos existentes na história e da legalidade das relações de dominação, não fora discutido em seus fundamentos até o século XVIII. Notase, então, uma aceitação ampla das relações de dominação e das relações entre senhores e servos, junto com a escala de suas variações, sem que se presencie modificações significativas nos seus aspectos histórico-semânticos.

Deve-se ao Estoicismo e ao Cristianismo o reconhecimento dos escravos, dos servos e dos seres humanos dependentes em sentido amplo, consequência de suas doutrinas acerca da liberdade interior. Para o primeiro, todos os seres humanos igualmente portadores de liberdade. Para o segundo, a liberdade é concebida através da fé. Esse reconhecimento pôde influenciar de variadas formas, mas não significou grandes mudanças sociais, e "jamais uma doutrina teológica ou moral relativa à liberdade interior questionou como instituição a ausência de liberdade, a instituição da servidão, da vassalagem ou da escravidão, cuja mais terrível expansão ocorreu na Idade Média". (KOSELLECK, 2012, p. 114)2.

O termo Emancipatio designava na República romana o ato jurídico mediante o qual o pai de família podia liberar seu filho do poder familiar. A partir desse ato, o filho separava-se completamente da família, passando, segundo o direito civil, a ser livre. O filho não emancipado possuía o direito de cidadania, de comercializar, de contrair matrimônio, mas não detinha o direito de dispor livremente de sua propriedade. Na República romana não existia o direito de liberar-se do direito do pai de família. Essa liberação tornou-se gradualmente possível ao longo do último período da República romana e durante o Império, mediante atos administrativos que favoreciam a formação de uma família própria (KOSELLECK, 2012). 
$\mathrm{Na}$ Idade Média esse termo técnico foi utilizado no âmbito do direito consuetudinário germânico. $\mathrm{O}$ direito germânico permitia obter a independência jurídico-civil ao chegar à idade adulta, que se adquiria mediante matrimônio, com a independência econômica, ou a posse de cargos e de dignidades. Nesse momento, a expressão perdeu o significado próprio do âmbito jurídico romano, que consistia num ato unilateral do pai de família, e passou a ser utilizado, em geral, para designar a maioridade ou a maturidade a que se chegava, de forma natural, aos vinte e cinco anos de idade.

Assim sendo, o uso linguístico do termo se tornou flexível e "emancipação" passou então a ser compreendida como liberação concedida antecipadamente. Por volta do início do século XVIII, o estado de independência assim obtido também podia ser descrito como emancipação. Desta forma, a interpretação jurídica romana perdeu seu monopólio conceitual. Já se incorporava às proposições das teorias jusnaturalistas anteriores ao lluminismo, que a emancipação, e com ela a capacidade legal, se alcançava de forma natural, uma vez chegada a maioridade. Desde então a relação entre as condições naturais e a aquisição da capacidade legal seria inerente à expressão emancipação (KOSELLECK, 2012).

A partir do século XVIII, o privilégio de exercer o poder sobre os homens se converteu na noção de que: o poder só pode ser o poder das pessoas aptas sobre si mesmas. De uma afirmação acerca do poder sobre si mesmo, interpretada anteriormente pela filosofia moral, se passou ao postulado político segundo o qual a liberdade interior só pode existir se também se faz efetiva exteriormente. (KOSELLECK, 2012).

A novidade dessa posição consiste em um certo grau de certeza sobre aquilo se compreendia com o termo "emancipação". Aí, então, está posta a questão da liberação completa e definitiva dos seres humanos relativamente ao domínio de outros seres humanos. A emancipação que se espera dessa transformação, a esperada liberação dos seres humanos da dominação de outros seres humanos, sua tentativa de realização histórica e a superação da alienação, jamais acontecera no passado em lugar algum. Esse tema e conceito, até então restritos ao domínio exclusivamente europeu, tomaram a figura conceitual de um domínio do pensamento universal, a partir do século XVIII. (KOSELLECK, 2012).

No entanto, as diferenças jurídicas e de direitos realmente existentes, as dependências feudais e os privilégios sociais que implicavam e que se estendiam ao conjunto da constituição política, econômica e social, não foram afetadas por nenhuma noção de emancipação até o início do século XVIII. Toda emancipação, tanto se se realizava unilateralmente, quanto se se 
produzia mediante um processo natural, pressupunha dominação. No sistema feudal era possível ser servo durante toda a vida; não existia termo legal que indicasse uma liberação geral do poder. Esse foi, precisamente, o significado que adquiriu no final do século XVIII o termo emancipação e, sem dúvida, não foi na linguagem jurídica, mas no uso psicológico, social, político e filosófico da palavra que a transformação decisiva dos seus usos semânticos efetivamente verificou-se. A ampliação do significado de emancipação, que possuía em definitivo um potencial revolucionário, desde as limitadas relações e formas de comportamentos contempladas no direito civil às relações humanas em geral, não se levou a cabo senão através do uso substantivo de emancipação, utilizado no direito civil. Todavia, tal princípio se produziu mediante o uso verbal e adverbial desta expressão, num processo que se pode observar a partir da perspectiva da história da linguagem e da história da sociedade (KOSELLECK, 2012).

Em latim o uso do verbo Emancipare era transitivo e podia significar vender e alienar. Segundo Koselleck, com o uso nas línguas vernáculas da Europa ocidental na sua forma substantiva e verbal - na Itália e na França no século XIV e na Inglaterra e na Alemanha no século XVII - surgiu a forma reflexiva de uso que, partindo do sentido existente no direito consuetudinário relativo à maioridade, terminou por indicar uma auto-habilitação, algo que precisamente a linguagem jurídica excluía. Que alguém pudesse emancipar-se a si mesmo era impensável na tradição do Direito Romano (KOSELLECK, 2012).

Pode-se formular a hipótese de que a aparição do uso verbal-reflexivo, no sentido de emancipar-se, foi indicador de uma profunda transformação de mentalidade que posteriormente se acelerou. No início, o uso da palavra era próprio dos intelectuais, dos poetas e dos filósofos que tentavam liberar-se de toda norma e dependência; posteriormente o novo ativismo da palavra passou a se referir cada vez mais a grupos, a instituições e a povos inteiros (KOSELLECK, 2012).

\section{O Humanismo}

O Humanismo, enquanto movimento filosófico e cultural que toma como fundamento o conceito de natureza humana, os seus limites e interesses, representa um reconhecimento do valor humano em sua completude, foi um elemento decisivo para o desenvolvimento conceitual do sentido de "emancipação". Esse movimento em seu significado histórico resulta do esforço 
em reconhecer o valor do ser humano em sua totalidade, compreendendo-o em seu mundo histórico e natural.

Esta visão de mundo, como atitude e fundamento do filosofar sobre o homem, origina-se na Grécia e toma esta como uma realidade espaçotemporal. Assim, nos textos clássicos podemos encontrar elementos que constituem a noção de dignidade e de liberdade do homem, exigindo a realização de direitos fundamentais e das condições corporais, intelectuais e emocionais dos indivíduos. Existe uma relação entre a noção de humanismo e a leitura de seus textos, começando pelos gregos e pelos romanos. Peter Sloterdijk na obra Regras para o parque humano afirma que "o que desde os dias de Cícero se chama humanitas faz parte, no sentido mais amplo e no mais estrito, das consequências da alfabetização" (SLOTERDIJK, 2000, p. 7).

No sentido em que a comunicação escrita definiria a natureza e a função do humanismo, sendo sua expressão os gêneros literários e filosóficos recepcionados na história, de uma era a outra, dos gregos aos romanos, e assim sucessivamente. Dessa forma pressupondo um modelo de sociedade literária. $\mathrm{E}$, no decorrer do tempo, em seu desenvolvimento histórico conceitual, se caracterizou como uma visão de mundo e de sistemas éticos cujas principais características são: a aceitação do humano como valor fundamental, a defesa da igualdade de todos os seres humanos, a afirmação da liberdade humana, o reconhecimento e a valorização da diversidade humana, a defesa da dignidade humana através de um pensamento emancipador, o repúdio de todas as formas de violência e o desenvolvimento de uma consciência histórica de verdade (BOMBASSARO, 2003).

Assim sendo, na segunda metade do século XIV, nasceu na Itália ${ }^{3} 0$ humanismo cívico enquanto movimento filosófico, literário e político que se difundiu pela Europa, estando na origem da cultura moderna e influenciando também a compreensão da situação humana. Nesse movimento, autores como Caluccio Salutati, Leon Batista Alberto, Lorenzo Valla e outros, elaboraram grandes discursos sobre liberdade, república, governo e leis, discursos sobre a vida ativa versus a vida contemplativa, numa proposição de mudança do modo do ser humano enfrentar a vida, passando da heteronomia para a autonomia.

De forma geral, também pode ser entendido a partir de tendências filosóficas que consideram as possibilidades e as limitações do homem, redimensionando os problemas filosóficos, seja via teorias que têm no ser humano o centro da realidade e do saber, ou via teorias que buscam defender a dignidade humana diante das forças que a ameaçam. Giovanni Pico Della Mirandola em $O$ discurso sobre a dignidade do homem, escrito em 1487, obra marcante no movimento humanista e na filosofia do Renascimento, expressa 
uma imagem nova do homem e do mundo no contexto da história da filosofia. O homem é uma natureza multiforme e cambiante, cuja essência livre e criadora de si mesmo corresponde a sua substancialidade como criatura de Deus por excelência. É livre, capaz de decidir seu destino e cumprir sua natureza. É um ser entre dois mundos, celeste e terrestre, e dois tempos, finitude e eternidade. É um ser dotado de corpo, de sensibilidade e de razão, descrito como a mais perfeita criatura de Deus, portador de uma natureza indefinida e que deve ser concretizada de acordo com sua essência. A natureza humana, a animal e a divina coexistem no homem, microcosmos de toda a realidade, para o qual Deus teria Ihe dito:

\begin{abstract}
Ó Adão, não te demos nem um lugar determinado, nem um aspecto que the seja próprio, nem tarefa alguma específica, a fim de que obtenhas e possuas aquele aspecto, aquela tarefa que tu seguramente desejares, tudo segundo o teu parecer e a tua decisão. A natureza bem definida dos outros seres é refreada por leis por nós prescritas. Tu, pelo contrário não constrangido por nenhuma limitação, determiná-laás para ti, segundo teu arbítrio, a cujo poder te entreguei. Coloquei-te no meio do mundo para que daí possas olhar melhor tudo o que há no mundo. Não te fizemos celeste nem terrestre, nem mortal nem imortal, a fim de que tu, árbitro e soberano de ti mesmo, te plasmasses e te informasses, na forma que tivesses seguramente escolhido. Poderás degenerar até aos seres que são as bestas, poderás regenerarte até as realidades que são divinas, por decisão do teu ânimo (PICO DELLA MIRANDOLA, 2011, p. 57).
\end{abstract}

Ser ontologicamente de natureza indeterminável e indefinida, diferenciando-se tanto do mundo natural quanto do divino e, também, ser artífice de si mesmo, estas são características do ser humano cunhadas por este autor. Há também uma afirmação da razão e do seu poder indagador na medida em que envolvem uma possibilidade de compreender, sendo o filósofo o ser privilegiado por ter como atributo o discernir com reta razão e a filosofia caracterizada como um discurso dessa mesma razão. E é por via dessa capacidade racional que o homem toma consciência de sua dimensão como ser livre.

A tematização do antropocentrismo em Pico Della Mirandola origina-se, especialmente, da consideração e da constatação da liberdade humana desdobrada para a ação ética, portanto, com alcance prático, mas articulando um nível ontológico. Dessa forma, temos a tese que afirma ser o homem, um ser de natureza indefinida, possibilidade de tudo ser, estando condenado a escolher, condenado à liberdade, por parte de Deus.

Do fato de o homem se constituir como um ser de natureza indefinida não significa uma pobreza em sua definição. Essa tensão ontológica funciona como um pré-reflexivo ou um pré-categorial que deve ser determinado a partir 
da ação. Ele possui o poder de se autodeterminar e, desse modo, coloca-se acima do mundo físico-biológico. A autodeterminação permite que ele eleve-se até Deus e que se apresente, na relação com as outras partes do mundo, como dinamizador dessas relações. Assim, possibilita-se a constatação, posterior na história da filosofia, que a dignidade humana não pode ser separada do princípio de que ela governa os elementos e controla a natureza. Essa será uma característica da Modernidade e uma das razões do papel que a ciência experimental e a tecnologia passarão a ocupar na vida humana, marca de uma nova ciência e de uma nova tecnologia.

O humanismo, em seu desenvolvimento greco-romano e o humanismo cívico, enquanto movimento filosófico e literário que surgiu na Itália, encontramse na origem da cultura moderna e assim influenciaram a compreensão do conceito de emancipação. Tomaram como fundamento a natureza humana, exaltaram a liberdade e a dignidade do homem, exploraram os limites e os interesses humanos e reconheceram o valor humano em sua completude e igualdade. Ou seja, influenciaram, fazendo uma defesa da dignidade humana através de um pensamento emancipador, repudiando todas as formas de violência e desenvolvendo uma consciência histórica de verdade (BULLOCK, 1989).

\section{O lluminismo}

O movimento iluminista é fruto da reunião de diversos atores em torno de um esforço intelectual na perspectiva de desenvolver as artes, as leis, a moral e as ciências. Esse importante movimento tinha como objetivo utilizar os novos conhecimentos criados para enriquecer a vida dos seres humanos e para propiciar a emancipação. Através do aumento do conhecimento científico da natureza, buscava-se liberar os seres humanos da miséria e da escassez. Através do desenvolvimento da racionalidade, do pensamento e das formas de organização em sociedade, buscava-se a emancipação das irracionalidades dos mitos, das religiões, das superstições, dos diferentes arbítrios de poder e do lado sombrio da própria natureza humana. O objetivo era desvelar as qualidades eternas, imutáveis e universais de toda a humanidade.

Para Ernest Cassirer, na sua obra A filosofia do lluminismo, a história das ideias dessa época é dominada pela visão da natureza, da sociedade e da arte, por um pequeno número de grandes ideias fundamentais que nos são propostas numa síntese coerente e segundo uma articulação rigorosa. $O$ lluminismo foi o primeiro movimento a descobrir e a afirmar a doutrina da razão 
emancipada, impondo-a em todos os domínios da vida do espírito. Nesse sentido, toda volta ao passado constitui um ato de conscientização e de autocrítica filosófica, um retorno autocrítico sobre si mesmo (CASSIRER, 1997).

No lluminismo o pensamento move-se pela questão de sua própria natureza e de seu próprio saber. Ele está menos fascinado pelas criações da ciência, da técnica, da atividade produtiva, do que pelo seu modo de ação. É nesse sentido que se apresenta para o conjunto do século XVIII o problema do progresso intelectual. Ao lado da ampliação quantitativa, encontra-se uma determinação qualitativa. A diversidade, a variedade das formas são a expressão do desenvolvimento e o desdobramento de uma força criadora única designada pelo nome de razão. A razão é o ponto de encontro e o centro de expansão desse século. Esse movimento considera a razão uma energia, uma força que só pode ser plenamente percebida em sua ação e em seus efeitos (CASSIRER, 1997).

O seu ideal de pensamento é formulado a partir do conhecimento físicomatemático na esteira da obra de Isaac Newton, Regulae Philosophandi como obra paradigmático desse período. Renuncia ao modo e a forma metodológica da dedução, da derivação e da explicação sistemática, a via a da análise, desse ideal de pensamento newtoniano. Os fenômenos tornam-se os dados e os princípios tornam-se aquilo que deve ser descoberto. Esse é o novo paradigma metódico que se encontra presente em todo o pensamento do século XVIII (CASSIRER, 1997).

O ser humano é compreendido a partir da sociedade, do Estado e da Razão. Nesse sentido, tanto a anuência quanto a obediência passiva encontram seus limites, que são suspensos. E a sociedade é colocada diante do tribunal da razão, no qual se questiona a legitimidade de seus títulos, os fundamentos de suas verdades e sua validade. Na filosofia política e social do século XVIII se consolida o método de resolução e de composição, a sociedade é analisada a partir da física e da psicologia analítica. Temos, assim, na obra Tratado dos sistemas, de Condillac, e na obra Do espírito das leis, de Montesquieu, uma reconstrução dos regimes políticos a partir das forças que constituem tais regimes (CASSIRER, 1997).

Neste momento se apresenta como fundamental à relação entre a sociedade burguesa moderna, a tecnologia e a política. Na abordagem dessa relação entre conhecimento, poder e possibilidade de decisão política a obra Crítica e Crise, de Reinhart Koselleck, se mostra exemplar, pela amplitude rigor da aplicação da metodologia da história dos conceitos, da qual ele é um dos expoentes maiores. Nesse sentido, diante das transformações ocorridas na 
Europa no século XVIII, e com o lluminismo enquanto um programa teórico e também pedagógico que identificava na razão como a única instância normativa capaz de produzir o avanço da humanidade; a partir do projeto de submeter à crítica a religião, a arte, a moral, a sociedade e a política, esse ideal normativo do lluminismo, juntamente com a noção de progresso, impulsionaram as transformações que possibilitaram a ascensão da burguesia ao poder. Essa associação da crítica ao progresso presidiu o entendimento da política da Revolução francesa, e foi nesse período que se formou a compreensão hegemônica da política.

Quanto ao elemento político desse processo, Koselleck afirma que:

\begin{abstract}
A ordem política que o Estado produziu ao pacificar o espaço devastado pelas guerras civis religiosas criou a condição necessária ao desenvolvimento do mundo moral. Contudo, na medida em que os indivíduos sem poder político se desvencilham do vínculo com a religião, eles entram em contradição com o Estado, que os emancipa moralmente, mas também os priva de responsabilidade, a reduzilos a um espaço privado. Os cidadãos entram necessariamente em conflito com um Estado que, pela subordinação da moral à política, entende a esfera política de maneira formal e age sem considerar a vertente própria da emancipação. O objetivo dos cidadãos será aperfeiçoar-se moralmente até o ponto de saber efetivamente, e cada um por si, o que é bom e o que é mau. Assim, cada um torna-se um juiz que, em virtude do esclarecimento alcançado, considera-se autorizado a processar todas as determinações heterônomas que contradizem sua autonomia moral. Assim, a separação, realizada pelo Estado, entre política e moral volta-se contra o próprio Estado, que é obrigado a aceitar um processo moral (KOSELLECK, 1999, p. 15-16).
\end{abstract}

Planejar a história torna-se tão importante quanto dominar a natureza. E no Estado tecnicista, incapaz de se fazer compreender enquanto construção política e como tal favorece a ideia equivocada, segundo o autor, que a história seja planificável. A separação entre moral e política, e a alienação da moral com relação a esta última, fez com que o lluminismo não compreendesse 0 caráter de destino da política, não no sentido de uma fatalidade cega. A tentativa de negar, pela filosofia da história, a facticidade histórica e de reprimir a política, tem em sua origem um caráter utópico. Enquanto a história é alienada pela filosofia da história, permanece a crise desencadeada pelo processo que a moral fomenta. E, também, nesse processo fixado pela filosofia da história a política foi reduzida, enquanto tarefa constante da existência humana, a construções utópicas do futuro (KOSELLECK, 1999).

A filosofia do lluminismo, na sua relação com o direito, o Estado e a sociedade, fez a reivindicação do direito de anterioridade da razão e, a partir disso, lutou em todos os domínios contra o poder dos costumes, das tradições e das autoridades. Objetivava em suas revoluções a restituição integral da razão e da humanidade em seus antigos direitos. Nesse movimento, vinculou- 
se ao humanismo renascentista, e utilizou esta herança de forma mais livre, e assim se movimentou quanto ao problema do direito, não se mantém nas considerações dos direitos historicamente adquiridos, mas remete-se aos direitos dos seres humanos adquiridos no nascimento (CASSIRER, 1997).

Quanto ao problema do direito, aderiu à ideia de que devem existir normas jurídicas absolutas e universalmente válidas, obrigatórias e imutáveis. Voltaire e Diderot, no entanto, chegaram a um dilema, quanto à possibilidade de conciliar a necessidade e a imutabilidade da ideia de direito com a tese de que as ideias provêm dos sentidos. Para Voltaire, a existência de um princípio universal da moral é a forma que ele encontrou para tratar dessa situação e é pela analogia às leis da natureza que ele recorreu para mostrar essa tese. Em Diderot, a crença na natureza moral e imutável, e na estabilidade do princípio de justiça que daí provém, permaneceu inabalável, percorrendo assim ele o caminho que vai de uma fundação a priori da ética até o de uma fundação utilitária (CASSIRER, 1997).

A doutrina dos direitos do homem e do cidadão desenvolvida nesse período foi edificada sob as fundações preparadas pelos teóricos do Direito Natural. A filosofia do lluminismo não descobriu a doutrina dos direitos inalienáveis, mas, no entanto, foi a primeira a fazer dessa concepção um evangelho moral, defendendo-o e proclamando-o com paixão e entusiasmo. A obra de Voltaire é inspirada e sustentada por este pensamento. Em Condorcet temos a afirmação de que o objetivo das ciências da sociedade humana é garantir aos homens o livre uso de seus direitos fundamentais em perfeita igualdade e na mais ampla medida. Condorcet credita as origens dessas ideias às filosofias dos séculos XVII e XVIII e atribui a Rousseau a elevação da teoria dos direitos do homem à categoria de verdade (CASSIRER, 1997).

Os enciclopedistas, e Diderot principalmente, defendiam a convicção da confiança no progresso da cultura intelectual e que esse implicaria numa ordem social nova e de melhor forma. O refinamento dos costumes, o aumento e a expansão do conhecimento científico transformariam e confeririam um fundamento seguro à moralidade. Diderot resume seus esforços na obrigação moral de popularizar essas ideias. $\mathrm{E}$ as ideias humanistas defendidas por ele eram aquelas cuja realização passava pela publicização; a sua realização encontrava-se condicionada por essa passagem para a sociedade. A obra Enciclopédia buscou instaurar e assegurar esta união, nela a ciência adquire sua função social e busca o desenvolvimento via uma sólida organização social baseada nesses princípios científicos e epistemológicos. Assim, os esforços éticos e políticos encontraram seus espaços a partir da expansão dessa cultura do espírito que se adquire em sociedade (CASSIRER, 1997). 
Rousseau considerou problemática e contestável a unidade admitida pelos enciclopedistas entre consciência moral e consciência cultural em geral. Para ele o domínio do querer encontra-se separado do domínio do saber, opondo-se tanto por seus fins como por seus meios. Quanto a essa organização social que os enciclopedistas compreendiam como a verdadeira humanidade, ele a entende como desprovida de todo impulso moral, calcada no instinto do poder e da propriedade, na ambição e na vaidade (CASSIRER, 1997).

Ele acredita e defende as artes e as ciências, as considera importantes para a edificação da sociedade, no entanto, esse papel só pode ser desempenhado pelas artes e pelas ciências a partir de uma nova fundação da sociedade. Somente se escapará da desordem existente, desordem que está no polo oposto da verdadeira liberdade, abolindo a ordem existente, demolindo as fundações do edifício político e social e construindo outro sobre alicerces mais seguros. As ciências devem renunciar à reivindicação do primado absoluto do domínio dos valores espirituais que se relacionam com a vontade moral. Na sociedade humana a construção do mundo do saber deve ser precedida pela elaboração clara e segura do mundo da vontade. O ser humano deve retornar a sua condição de natureza, e percorrer novamente todo o caminho desde a origem, para encontrar primeiro em si uma lei firme. Mesmo erguendo-se contra a filosofia do lluminismo, Rousseau continuou sendo um herdeiro dessa filosofia; ele não destruiu o universo do século XVIII, mas 0 deslocou do seu centro de gravidade (CASSIRER, 1997).

O lluminismo formulou a questão da liberação completa e definitiva dos seres humanos do domínio de outros seres humanos. Neste momento, também, apareceu a utilização do uso verbal reflexivo desta noção, emanciparse, denotando a possibilidade de autoemancipação. Diante das mudanças ocorridas na Europa no século XVIII e com o lluminismo enquanto um programa teórico e pedagógico que identificava na razão a única instância normativa promotora do avanço da humanidade, através de um projeto de crítica e de uma noção de progresso, que acabou impulsionando essas mudanças. Com as concepções de unidade do mundo, de caráter histórico e filosófico, comprometidas com o progresso, compreendem os conflitos como categorias da história com a possibilidade de superação e de emancipação ou autoemancipação.

\section{Ciência e tecnologia}


A ciência e a tecnologia, juntamente com a metafísica, a filosofia da história e a antropologia filosófica, com os movimentos humanismo e 0 lluminismo, fundamentam as discussões em relação ao desenvolvimento histórico conceitual de emancipação. Nesse momento abordamos a ciência e a tecnologia. Sobre a ciência, de forma geral, ela designou na história da humanidade dois fenômenos: o primeiro diz respeito à representação que o ser humano faz do mundo, em diferentes grupos humanos e em diferentes civilizações e o segundo diz respeito à ciência moderna.

A ciência moderna trata sobre a representação de mundo desenvolvida pela civilização ocidental a partir do século XIV. É uma forma de representação que possui antecedentes na Antiguidade, mas que nasce propriamente na Idade Média e se desenvolve, principalmente, na Idade Moderna, tornando-se um modo específico de conhecimento adotado por essa civilização. Tratar do desenvolvimento da ciência moderna exige um estudo detalhado do contexto histórico e de seu desenvolvimento que, enquanto análise e construção teórica, também se liga a ideologia. Nesse sentido, não pretendemos fazer uma reconstrução histórica da origem e desenvolvimento da noção de ciência moderna, mas sim, destacar algumas ideias que estão na origem desse fenômeno e que podem nos auxiliar na compreensão fenomênica da ciência dentro da perspectiva da noção de emancipação.

Na obra $A$ construção das ciências, Gérard Fourez faz uma descrição da ciência moderna destacando a relação que ela possui com a burguesia - com a classe social que surge na Idade Média e que suplanta, posteriormente, a aristocracia enquanto classe dirigente ou hegemônica na civilização ocidental. Nesse sentido, em seu caráter ativo, que busca permitir ao ser humano agir sobre a natureza dominando-a pela previsão dos fatos possibilitados por lei, tem como elemento que a possibilita uma nova visão de mundo, distinta substancialmente da visão de mundo que foi hegemônica no período da Antiguidade até o século XII. Essa nova visão de mundo é a da cultura burguesa que condicionou a origem e o desenvolvimento da ciência moderna. Noções como as de objetividade pura e de uniformização da percepção de mundo, que se encontram na raiz do método científico, originam-se na tradição burguesa da comunicação. Visto que a cultura burguesa cria representações mentais que qualquer ser humano poderia isolar, interiorizar e até comunicar, mesmo sem compreender, enquanto que em outras culturas e em momentos anteriores, pressupunha-se, para se comunicar, um compartilhamento total do mesmo meio. O que mostra o vínculo existente entre os métodos modernos de escrita e leitura e a ciência moderna (FOUREZ, 1995).

A mentalidade burguesa origina-se do desejo de dominar e controlar a 
natureza, a sociedade, enfim, o seu meio. E essa é outra diferença em relação à mentalidade anterior. A moral, por exemplo, na modernidade se desenvolve como controle das paixões e no domínio de si. Todo o universo capitalista de produção, distribuição, consumo, constrói-se a partir dessa noção unidimensional do comerciante burguês, como destaca Herbert Marcuse na obra $A$ ideologia da sociedade industrial. Nesse universo da racionalidade burguesa e da ciência moderna, os objetos perderam aquilo que constituía a sua particularidade e tornaram-se objetos de cálculo e de domínio:

\begin{abstract}
A ciência moderna ligou-se dessa forma à ideologia burguesa e a sua vontade de dominar o mundo e controlar o meio ambiente. Nisso ela foi perfeitamente eficaz. Foi um instrumento intelectual que permitiu à burguesia, em primeiro lugar, suplantar a aristocracia e, em segundo, dominar econômica, política, colonial e militarmente o planeta (FOUREZ, 1995, p. 163).
\end{abstract}

A ciência moderna surge como um modo específico de conhecimento desenvolvido no Ocidente e ligado à burguesia. Esse surgimento dá-se via uma ruptura com o meio sacralizado da Idade Média, através do surgimento de um novo paradigma do conhecimento burguês baseado na interioridade, na objetividade, no cálculo, na compreensão e no domínio.

A eficácia do método empregado pela ciência moderna é utilizada como fundamento para a noção de progresso. A ideologia dessa noção baseia-se na noção de um saber universal e de um progresso constante. $\mathrm{E}$ os benefícios gerados pela produção na sociedade burguesa, com a ciência e a tecnologia, foram enormes. A vida humana encontrou melhorias e a grande maioria da população mundial se beneficiou destes avanços, dados principalmente enquanto bem-estar econômico e social. No entanto, as recentes evoluções da sociedade burguesa geraram, por exemplo, problemas no meio ambiente, problemas energéticos, corridas armamentistas, entre outras, que possibilitaram um questionamento crescente dessa atitude de domínio, próprio dessa sociedade. Dessa forma, abre-se uma dimensão de questionamentos dos limites dessa gestão técnico-científica de cunho burguês, visto sua incapacidade de resolver os problemas sociais do mundo, sua incapacidade de suprimir as dominações humanas, sua incapacidade em resolver questões éticas e sociopolíticas da humanidade e o de possuir um papel ativo no estabelecimento das desigualdades mundiais (FOUREZ, 1995).

Ciência e tecnologia encontram-se de tal forma ligadas que se torna difícil determinar quais são aqueles aspectos diferenciados que as qualificam como atividades técnico-científicas específicas de cada uma. Quanto à evolução da ciência, ocorreu um processo de esquecimento de suas origens, das questões cotidianas que a fizeram surgir, e daí evoluiu para a pretensão da existência de uma ciência universal. Imperou a crença de que tudo dependia de 
raciocínios, de um discurso científico, que obedeceria à racionalidade, independentemente da época ou lugar. Houve uma supressão da dimensão histórica na história da ciência, na qual se procurou mostrar o desenvolvimento de forma linear e inexorável do processo científico, no qual se relata a posteriori aquilo que se considera útil, científico e racional (FOUREZ, 1995).

Jürgen Habermas, na obra Perfiles filosófico-políticos, apresenta, entre outros, o pensamento de Adorno, fazendo uma discussão a partir dos conceitos adornianos de natureza e de subjetividade e apresenta o conceito de tecnologia desenvolvido nessa relação. Assim, na Dialética do esclarecimento, Adorno e Horkheimer, se valem da obra Odisseia e de alguns episódios da viagem de Ulisses para mostrar que a subjetividade adquire sua organização interna na medida em que, para submeter a natureza externa, submete-se a si mesmo, sua natureza interna. Nesse sentido, a história da civilização origina-se de um ato de violência sofrido pelo ser humano e pela natureza. $E$ desenvolvimento do espírito instrumental, via o crescente poder de disposição técnica, representa esta história da renúncia da subjetividade e do desenvolvimento tecnológico das forças produtivas. Para Adorno, a dominação da natureza externa somente pôde ocorrer pela repressão da natureza interna, da subjetividade (HABERMAS, 1975).

A metáfora da dominação da natureza ressoa essa junção do poder de disposição técnica com a dominação institucionalizada, pois, o domínio sobre a natureza vincula-se à dominação introjetada do ser humano, e do ser humano para com o ser humano, a dominação que exerce o sujeito sobre sua própria natureza. A autoconsciência iluminista, lembra Adorno, insiste nessa relação de autonomia do Eu e de dominação da natureza. O espaço de liberdade que desenvolve a disposição técnica revela que os sujeitos foram mutilados por esse processo instrumental, nisso encontra-se a irracionalidade da llustração que não refletiu sobre si mesma. De uma racionalidade realizada, responsável pelo desenvolvimento material, mas viciada pela coerção do instinto de natureza, neste sentido, a tecnologia é a própria negação da natureza (HABERMAS, 1975).

Trata-se de um ato de autoafirmação violenta que representa a disposição técnica sobre a natureza externa e a repressão da natureza interna. Nesse ato talvez se possa dizer que ao adotarmos frente à natureza a atitude metódica da ciência e da técnica, reprimindo-a, deixando-a aparecer somente na perspectiva de nossos imperativos no lugar de aprendê-la e tratá-la a partir dela mesma, reprimimos também a nossa natureza interna e os elementos de nossa subjetividade (HABERMAS, 1975).

Entretanto, Umberto Galimberti na obra Psiche e techne parte do 
pressuposto de que vivemos na idade da técnica, pois gozamos dos benefícios e usufruímos dos bens e dos espaços de liberdade proporcionados pela tecnologia. A partir desse pressuposto gera-se o questionamento de, se a nossa compreensão do ser humano, com seus traços pré-tecnológicos e seu horizonte de sentido, seria a mais adequada nessa nova idade. Essa aboliu, segundo Galimberti, o cenário de sentido humanista, entretanto, "as demandas de sentido continuam desatendidas, não porque a técnica não esteja bastante aperfeiçoada, mas porque não se enquadra em seu programa encontrar respostas para semelhantes demandas" (GALIMBERTI, 2006, p. 8).

Dessa forma, temos que a técnica objetiva a funcionalidade, ela não possui outros objetivos como a constituição de sentido, de verdade, de salvação ou de redenção. O que implica na necessidade de revermos uma série de conceitos que foram constituídos na idade pré-tecnológica e que devem ser revistos, abandonados ou ressignificados. Trata-se, portanto, de pensarmos as categorias herdadas, se essas ainda são aptas para compreender o ser humano e de desconsiderar todas as categorias que continuam a compreender o ser humano fora de suas condições de existência concretas e reais (GALIMBERTI, 2006).

O conceito de técnica assumido por Galimberti é descrito nos seguintes termos:

Com o termo "técnica" entendemos o universo de meios (as tecnologias), que em seu conjunto compõem o aparato técnico, quanto a racionalidade que preside o seu emprego, em termos de funcionalidade e eficiência. Com essas características, a técnica nasceu, não expressão do "espírito" humano, mas como "remédio" à sua insuficiência biológica (GALIMBERTI, 2006, p. 9).

A técnica é definida a partir de duas características: pelo universo dos meios e pela racionalidade, e se origina da insuficiência biológica do ser humano. Diferentemente dos demais animais, que são estabilizados por seus instintos, o ser humano possui essa carência instintiva que, por sua vez, é estabilizada pela ação que se encaminha para a técnica, "a antecipação, a idealização, a projeção, a liberdade de movimento e de ação, em suma, a história como sucessão de autocriações tem na carência biológica a sua raiz, e no agir técnico a sua expressão" (GALIMBERTI, 2006, p. 9). E a partir dessas condições apresenta a técnica enquanto essência do ser humano.

Neste sentido, afirma que se deve modificar o critério de compreensão tradicional da técnica enquanto instrumento a disposição, e a compreensão do ser humano enquanto sujeito, pois é uma realidade na qual a técnica:

De instrumento nas mãos do homem para dominar a natureza, se torna o ambiente 
do homem, aquilo que o rodeia e o constitui, segundo as regras daquela racionalidade que, seguindo os critérios de funcionalidade e da eficiência, não hesita em subordinar às exigências do aparato técnico às próprias demandas do homem (GALIMBERTI, 2006, p. 11).

A técnica se originou dentro do universo de controle, que se tornou universal, e que estava previsto pela ciência moderna. Por isso, a encontramos disseminada em todo o globo. No entanto, no início da modernidade o homem ainda podia reivindicar a subjetividade e o domínio sobre a instrumentação técnica, pois os meios técnicos ainda eram insuficientes. $\mathrm{Na}$ contemporaneidade, os meios técnicos desenvolveram-se de tal forma, enquanto força e extensão, que promoveram uma ruptura com a técnica moderna (GALIMBERTI, 2006).

$\mathrm{Na}$ contemporaneidade a técnica perde a característica de meio, próprio da modernidade que expressa a satisfação das necessidades humanas, "quando a técnica aumenta quantitativamente a ponto de se tornar disponível para a realização de qualquer fim, então muda qualitativamente o cenário" (GALIMBERTI, 2006, p. 12). Nesse novo cenário, "não é mais o fim que condiciona a representação, a pesquisa, a aquisição dos meios técnicos, mas será a ampliada disponibilidade de meios técnicos que desvela o leque dos fins que, por meio deles, podem ser alcançados" (GALIMBERTI, 2006, p. 12). A técnica se transforma de meio em fim porque os objetivos e fins que os homens se propõem somente podem ser atingidos pela mediação técnica. Essa viragem implica na necessidade de revisão das categorias com as quais o ser humano definia a si mesmo e a sua situação no mundo:

\begin{abstract}
Se a técnica se torna esse horizonte último a partir do qual se desvelam todos os campos da experiência, se não é mais a experiência que, reiterada, comanda o procedimento técnico, mas é a técnica que se coloca como condição a decidir o modo de se fazer experiência, então assistimos a uma reviravolta pela qual o sujeito da história não é mais o homem, e sim a técnica, que, emancipando-se da condição de mero "instrumento", dispõe da natureza como um fundo e do homem como um funcionário seu. Isso comporta uma revisão radical dos tradicionais modos de entender a razão, a verdade, a ideologia, a política, a ética, a natureza, a religião e a própria história (GALIMBERTI, 2006, p. 13).
\end{abstract}

A razão se tornou procedimento instrumental que garante o cálculo mais eficiente entre os meios à disposição e os objetivos que se pretendem alcançar. Em relação à verdade, a eficácia se torna o critério de verdade. As ideologias não resistem à redução de todas as ideias a simples hipóteses de trabalho. A política, que tem sua capacidade decisória condicionada pelo aparato econômico, que, por sua vez, está subordinado às disponibilidades 
garantidas pelo aparato técnico, apenas possui papel ativo onde a técnica ainda não é hegemônica. A ética, enquanto forma de agir visando fins, "sente a sua impotência no mundo da técnica, regulado pelo fazer como pura produção de resultados, em que os efeitos se adicionam de tal modo que os resultados finais não se remetem mais às intenções iniciais" (GALIMBERTI, 2006, p. 14).

O que significa dizer que é a técnica que escolhe os fins e encarrega a ética de encontrar os meios. A natureza, que mostra sua vulnerabilidade pelo efeito da técnica, abre-se num cenário no qual as éticas tradicionais emudecem, pois se limitaram a regulação das relações entre os seres humanos, sem extensão aos entes naturais, e não tem como acolher a natureza no âmbito da responsabilidade humana. Quanto à religião, a técnica substitui a dimensão escatológica do tempo pela dimensão projetual, subtraindo a possibilidade de ler no tempo um sentido, um fim último, ao qual se recorre para a salvação e a verdade. Por fim, quanto à história, o caráter afinalista da técnica que se move em vista de resultados que se originam de seus procedimentos, abole qualquer horizonte de sentido. A memória histórica, a memória procedimental da técnica reduz o passado ao superado e concebe 0 futuro enquanto aperfeiçoamento dos processos (GALIMBERTI, 2006).

A técnica promove uma supressão de todos os fins do universo dos meios, o absoluto é a categoria livre de qualquer vínculo, de horizonte de fins e de produção de sentidos, que a técnica reserva para si enquanto prerrogativa. Enquanto efeito dessa alteração, quem está inserido ou aciona o aparato técnico não se questiona se o objetivo pelo qual o aparato técnico foi colocado em movimento é justificável, se tem sentido, pois significaria duvidar da técnica, "sem a qual nenhum sujeito e nenhum objetivo seriam alcançáveis, então, a 'responsabilidade' é confiada ao 'responso' técnico, onde está subentendido ao imperativo: 'deve-se' fazer tudo que 'se pode' fazer' (GALIMBERTI, 2006, p. 16).

O ser humano encontra-se nesse universo de meios no qual o objetivo é o aperfeiçoamento e a potencialização da instrumentação. Torna-se um funcionário do aparato técnico e sua identidade se resolve nessa funcionalidade:

De fato, a técnica não é o homem. Nascida como condição da existência humana e, portanto, como expressão da sua essência, hoje, pelas dimensões alcançadas e pela autonomia adquirida, a técnica expressa a abstração e a combinação das idealizações e das ações humanas num nível de artificialidade de tal forma que nenhum homem, nenhum grupo humano, ainda que especializado, e talvez justamente por efeito de sua especialização, é capaz de controla-la em sua totalidade. Em tal contexto, ser reduzido a funcionário da técnica significa, então, para o homem, ser transferido "para outro lugar", em relação à habitação que 
historicamente conheceu; significa estar longe de si (GALIMBERTI, 2006, p. 17).

Essa condição do ser humano em relação ao aparato técnico foi descrita por Marx como uma condição de alienação, circunscrita ao modo de produção capitalista. Para Galimberti, tanto o capitalismo, quanto o comunismo projetado como superação da alienação, "ainda são figuras inscritas no humanismo, ou seja, naquele horizonte de sentido típico da idade pré-tecnológica, em que o homem é visto como sujeito, e a técnica como instrumento" (GALIMBERTI, 2006 , p. 17). Entretanto, a relação se inverte quando na idade da técnica o universo dos meios não tem nenhuma finalidade, o ser humano se torna um produto da alienação tecnológica, não mais um sujeito que é alienado, e é a técnica que se organiza enquanto sujeito. Segundo Galimberti, Marx foi o primeiro a antever a idade da técnica, no entanto essa visão se moveu no interior do horizonte humanista pré-tecnológico, enquanto no momento posterior, na idade da técnica, se deu um deslocamento, no qual somente restam as exigências racionais, a qual todos estão subordinados (GALIMBERTI, 2006).

Nessa ocorre também uma revisão das categorias humanistas. A noção de indivíduo não se dá mais "a partir da consciência da própria individualidade, pensa-se autônoma, independente, livre, até os limites da liberdade alheia e, por efeito desse reconhecimento, igual aos demais" (GALIMBERTI, 2006, p. 19). Não possui mais esse sistema de valores que fundamentava a concepção de indivíduo. Em relação à noção de identidade, as ações dos indivíduos não são mais entendidas enquanto expressão de sua identidade, mas sim como possibilidades calculáveis pelo aparato técnico, que as prevê e prescreve sua forma de execução, "o sujeito não revela a sua identidade, mas a do aparato, no seio do qual a identidade pessoal se resolve como pura e simples funcionalidade" (GALIMBERTI, 2006, p. 19). A noção de liberdade na idade da técnica é compreendida enquanto competência. A liberdade como competência se expressa no espaço impessoal das relações profissionais, e gera uma cisão entre o público e o privado, que comporta uma forma de condução nova e esquizofrênica da vida individual "que se manifesta toda vez que a função que cabe ao indivíduo como membro impessoal da organização técnica - entra em colisão com aquilo a que o indivíduo aspira ser como sujeito global" (GALIMBERTI, 2006, p. 20). Os indivíduos colocam-se em relações sociais sem que existam vínculos de natureza pessoal, o que finda na consideração da sociedade em termos exclusivamente instrumentais.

Essa cisão entre público e privado e entre social e individual no universo da racionalidade técnica, modifica também o conceito de massa, de cultura de 
massa e introduz-se:

\begin{abstract}
Uma variante que é a sua atomização e desarticulação em singularidades individuais que, modeladas por produtos de massa, consumos de massa, informações de massa, tornam obsoleto o conceito de massa como concentração de muitos, e atual o de massificação como qualidade de milhões de indivíduos, cada um dos quais produz, consome e recebe as mesmas coisas de todos, mas de modo solitário (GALIMBERTI, 2006, p. 20).
\end{abstract}

Nesse contexto é atribuída a cada indivíduo a massificação, mas com a aparência de privacidade. É um processo de desindividualização e de desprivatização próprio de sociedades conformistas e ratificadoras.

A noção de comunicação também é revista neste universo. Os meios de comunicação contribuem nesse processo de ratificação social. Esses foram potencializados pelo aparato técnico e modificaram o modo de se fazer experiência, "não mais em contato com o mundo, mas com a representação midiática do mundo, que torna próximo o longínquo, presente o ausente, disponível aquilo que, de outra forma, estaria indisponível" (GALIMBERTI, 2006, p. 21). Ocorre uma liberação da experiência direta e coloca-se uma relação não mais com os eventos, mas sim com sua representação. Nesse sentido, com os meios de comunicação é a própria informação codificada e os efeitos desse código que se tornam critérios interpretativos da realidade e modelos indutores de nossos juízos, consequentemente, de comportamentos. Nesse modelo, a experiência de comunicação desmorona porque se suprimem as diferenças específicas entre as experiências pessoais do mundo, que estão na base da comunicação. Neste momento, os meios de comunicação "ao intervir sobre a modalidade de fazer experiência, modificam o homem independentemente do uso que este faz deles e dos objetivos que se propõe quando os emprega" (GALIMBERTI, 2006, p. 21).

A noção de psique é alterada pela racionalidade técnica com essa dispensação da experiência pessoal do mundo, pois a psique se torna coextensiva ao mundo. Com essa alteração são suprimidas as diferenças entre interioridade e exterioridade, pois o conteúdo da vida psíquica termina coincidindo com a comum representação do mundo. São suprimidas também as diferenças entre profundidade e superfície, pois a profundidade é as regras do jogo reveladas a todos na superfície. E são suprimidas as diferenças entre atividade e passividade, pois se a tendência da sociedade tecnológica é a de potencializar a racionalidade, a atividade torna-se adaptação aos procedimentos técnicos que as possibilitam. Dessa forma, a psique não consegue compreender o significado de viver na idade da técnica, "em que o que se pede é uma potencialização das faculdades intelectuais sobre as 
emotivas, para poder estar à altura da cultura objetivada nas coisas que a técnica exige, em detrimento e à custa daquela subjetividade dos indivíduos" (GALIMBERTI, 2006, p. 22).

Trata-se de avançar na compreensão das discussões em torno da idade da técnica, abandonando a lógica binária da exaltação incondicional ou da demonização acrítica e de explorar:

O horizonte da compreensão, convictos como estamos de que hoje o horizonte da compreensão não é mais a natureza, em sua estabilidade e inviolabilidade, nem a história, que vivemos e narramos como progressivo domínio do homem sobre a natureza, mas a técnica, que desvela um espaço interpretativo que definitivamente se despediu tanto do horizonte da natureza quanto daquele da história (GALIMBERTI, 2006, p. 22).

Supera-se a certeza ingênua de que a natureza é algo estável, que permanece intacta, não importando a ação humana. A técnica prepara o ser humano para um mundo que se apresenta enquanto "ilimitada manipulabilidade, e por isso a natureza humana não pode ser pensada como aquela que se relacionava com um mundo que a história até agora nos descreveu, em seus limites, como inviolável e profundamente imodificável" (GALIMBERTI, 2006, p. 23). Mas, num momento em que a capacidade de produção superou a capacidade de imaginação, de modo que não é possível compreender e considerar os desenvolvimentos técnicos e sua produção, "assistimos à irracionalidade que nasce da perfeita racionalidade (instrumental) da organização técnica, que cresce por si mesma, fora de qualquer horizonte de sentido" (GALIMBERTI, 2006, p. 24).

\section{Metafísica, filosofia da história e antropologia filosófica}

A emancipação teve vários títulos de legitimação: a natureza, a razão ou a vontade livre. Instâncias que desde o lluminismo e com independência do conceito reflexivo de emancipação obrigam o poder tradicional a justificar-se ao tempo que o submetem à pressão da mudança. Essas instâncias repercutiram no conteúdo semântico ampliado de emancipação, o ato unilateral do poder estatal consiste em equiparar no âmbito do direito civil a um indivíduo mediante a emancipação - o que se observa na linguagem jurídica do Código de Napoleão - se viram sustentados pelas exigências daqueles que se sabiam legitimados para emancipar a si mesmos. Os títulos precedentes, natureza, razão e vontade livre vieram de um novo conteúdo próprio da filosofia da história ao conceito de emancipação (KOSELLECK, 2012). 
$\mathrm{Na}$ modernidade encontramos diversas teorias que fundamentam essa transformação no conceito de emancipação. Tratam-se da metafísica, da ciências e tecnologia, da filosofia da história e da antropologia filosófica. A metafísica é sustentada, segundo Walter Schulz, na obra El Dios de la metafísica moderna, desde a modernidade por uma concepção determinada numa continuidade surpreendente. Essa concepção compreende o sentido do pensamento metafísico em colocar em evidência a consciência de si autônoma. E é Hegel quem inicia essa interpretação na história da filosofia moderna de forma unitária e sistemática, definindo a marcha necessária do espírito absoluto até a compreensão de si mesmo como história da filosofia, concepção assumida em meados do século XIX. No entanto, houve uma modificação, no lugar do espírito absoluto se viu o homem real como o protagonista da história. Mas, ao mesmo tempo, se conservou o passado, o progresso continuou sendo considerado como a lei dominante da história, mas foi negada a apreciação positiva da evolução, conservando-se a ideia condutora que a história da metafísica moderna é um caminho seguro até a autonomia (SCHULZ, 1961).

$\mathrm{Na}$ metafísica moderna os renovados exames da subjetividade e do conhecimento da finitude da subjetividade humana se complementam reciprocamente. Esses exames da subjetividade possuem uma dupla orientação: primeiro, frente aos entes mundanos, apreendem a subjetividade humana com toda sua força. Neste sentido, Nicolau de Cusa, Descartes, Kant e Heidegger destacaram a subjetividade humana como a verdadeira condição do conhecimento. E, segundo, conheceram a impotência da subjetividade humana na relação consigo mesma, e por isso, colocaram sobre a subjetividade, reconhecida como finita, um poder inconcebível como seu fundamento essencial. Todos esses pensadores - Nicolau de Cusa, Descartes, Kant, Heidegger - pensam a subjetividade finita: colocam em relação com a transcendência que lhe corresponde com o outro dialético que não pode ser compreendido em si mesmo. E essa característica da metafísica moderna foi destacada pela primeira vez por Nicolau de Cusa (SCHULZ, 1961).

Em relação a antropologia filosófica, essa pertence essencialmente à tradição daquelas teorias filosóficas do homem que se denominam a si mesmas com o termo de antropologia. Segundo Odo Marquard, na obra Las dificultades con la filosofía de la historia. Ensayos, a sua tradição e a sua história é um produto da época moderna, não se deve a assuntos eternamente humanos ou filosóficos e, inclusive, o termo surge no século XVI. Surge mediante um duplo processo de rejeição, que se torna possível na época moderna, e essa é a primeira condição para sua origem: 


\begin{abstract}
Um processo de rejeição da filosofia, por uma parte, a respeito da "metafísica da escola tradicional", e por outra parte, a respeito das "ciências matemáticas da natureza". Essa dupla rejeição representa, de fato, uma virada até o mundo da vida e, enquanto tal, uma condição necessária da antropologia filosófica e de sua crescente importância (MARQUARD, 2007, p. 135) ${ }^{4}$.
\end{abstract}

As antropologias filosóficas para as quais o ser humano e o mundo da vida tornam-se questões centrais são, essencialmente, filosofias da natureza do ser humano e não englobam aquelas filosofias que são filosofias da história. E essa rejeição da filosofia da história mediante esse retorno à natureza é a segunda condição necessária para o surgimento e a importância da antropologia filosófica. Para Marquard, essas duas condições, a rejeição, de um lado, da filosofia enquanto metafísica tradicional e das ciências físicomatemáticas da natureza e, de outro, da filosofia da história, contêm a tese de que se designa à teoria filosófica do ser humano que se torna possível mediante a virada ao mundo da vida mediante o retorno à natureza (MARQUARD, 2007).

Essa tese se torna possível a partir da história do final do século XVIII e esse surgimento e desenvolvimento encontram-se na antropologia kantiana. A obra Antropologia de um ponto de vista pragmático representa a virada ao mundo da vida e ao nascimento da antropologia filosófica. E essa virada relaciona-se com a formação da noção de crítica da razão, segundo a qual, a metafísica tradicional se ocupa de coisas mentais, enquanto as ciências físicomatemáticas se ocupam de fenômenos, e o mundo da vida também exige uma filosofia, visto que esse não se pode reduzir à totalidade sem realidade do mundo do entendimento, nem a realidade sem totalidade do mundo dos sentidos. Por essa razão, define a antropologia como conhecimento do mundo que se pode alcançar pela experiência cotidiana e pelo aproveitamento de fontes e meios de auxílio. Em Kant, portanto, a antropologia filosófica que se estabelece no curso de uma virada ao mundo da vida é uma filosofia do mundo da vida (MARQUARD, 2007).

A filosofia da história é a outra filosofia do mundo da vida na modernidade. É uma filosofia do destino do homem que se desenvolve mediante a teoria da liberdade, como sua finalidade, e mediante a teoria do mundo histórico, como mediação progressiva dessa finalidade (MARQUARD, 2007).

Na relação existente entre antropologia filosófica e filosofia da história:

A antropologia escapa a essa posição subalterna no ponto preciso em que a filosofia da história se torna problemática e demasiado débil para entender a antropologia em seu campo de interesse. Chega a esse ponto de forma representativa na filosofia do 
Idealismo alemão, pouco antes do fim do século, quando o "progresso infinito" na história se torna opressivo enquanto demora infinita de sua meta. Essa crise da filosofia da história cria, em primeiro lugar, a filosofia romântica da natureza; a história aparece em tal extremo desprovida de esperança que somente pode-se considerar a não-história radical como agente da humanidade: a natureza (MARQUARD, 2007, p. 139).

A antropologia filosófica adquire no Romantismo uma posição fundamental, no entanto, Hegel retomará essa discussão buscando colocar a antropologia novamente no contexto da filosofia da história. Nesse sentido, na obra Enciclopédia das ciências filosóficas, realiza uma crítica que assume a forma de apropriação, e essa crítica enquadra-se dentro das polêmicas com a filosofia do Romantismo. Afirma que a teoria romântica centra-se no espírito natural, enquanto teoria do espírito em sua determinação natural e imediata mostra-se como uma filosofia do 'em si', sendo insuficiente para tratar os problemas da realização histórica. Assim, quando a filosofia da história só pode manter-se como teoria da possibilidade humana, logo, a tentativa hegeliana de adaptar a antropologia à filosofia da história implica a degradação da antropologia (MARQUARD, 2007).

O que nos leva a seguinte situação: nas filosofias do mundo da vida, a virada à filosofia da história só é possível quando se abandona a antropologia filosófica, e a virada para a antropologia filosófica só é possível se se abandona a filosofia da história, "por isso, quando em nome do mundo da vida se volta à filosofia da história, a filosofia contemporânea é crítica da antropologia" (MARQUARD, 2007, p. 146). E o que se mostra nessas filosofias que rejeitam a filosofia da história define a virada atual até a antropologia, "a história parece de novo tão desprovida de qualquer esperança que somente a não-história radical, a natureza, se salva como ponto de referência sólido ou ao menos praticável" (MARQUARD, 2007, p. 146). O que representa que o auge da antropologia filosófica constitui expressão da crise da história e da sua filosofia.

Os seguintes três fenômenos confirmam o auge da antropologia filosófica e a crise da filosofia da história. O primeiro diz respeito ao fato de a antropologia filosófica contemporânea recorrer ao texto de Max Scheler, $A$ posição do homem no cosmos, como obra fundamental dessa filosofia na contemporaneidade. O que é sintomático, pois, a obra de Scheler se distingue das demais obras dos anos vinte, do século XX, justamente por não conceber o homem em seus termos históricos e por destacar sua posição na natureza. É como teoria geral da vitalidade natural que Scheler fundamenta a pergunta pelo homem e, por precisamente essa fundamentação adquirir valor exemplar, corrobora a prevalência da natureza como referencial da antropologia filosófica contemporânea (MARQUARD, 2007). 
O segundo fenômeno é a influência crescente da obra de Arnoldo Gehlen, pois sua teoria do homem, em conexão com a teoria de Herder, radicaliza a fundamentação de Scheler, uma vez que abandona sua tese sobre o espírito e se orienta, em geral, até uma filosofia da natureza do homem. Essa interpreta "todas as generalizações - incluindo o espírito - como 'transferências' de sua situação natural deficiente e a cultura como um grande arranjo, cujo único objetivo é evitar a morte: os problemas do homem com a natureza tornam-se instâncias históricas" (MARQUARD, 2007, p. 147). O problema é que a teoria de Gehlen fala de transferências do homem, não de transferências de todos os homens. Ela justifica porque o homem não é um animal, mas não porque não possui o direito de ser inumano. $O$ que nos leva, novamente, a prestar atenção à esfera da determinação do homem, à história.

O terceiro fenômeno é o fato de que contemporaneamente apelem à antropologia filosófica as ciências cuja validade mantém uma relação disjuntiva com a validade da filosofia da história, e que, "por regra geral, se tornam filosoficamente ativas como compensações de uma filosofia da história incapaz de cumprir suas exigências: se trata, por exemplo, da pedagogia, da teologia e da medicina" (MARQUARD, 2007, p. 148).

Assim, temos como conceito filosófico de antropologia, não qualquer teoria filosófica do ser humano, mas aquelas que se tornam possível mediante a rejeição da metafísica tradicional, das ciências físico-matemáticas da natureza, mediante uma virada ao mundo da vida, que se tornam fundamentais via um retorno à natureza e mediante a rejeição da filosofia da história. Quando essa posição entre antropologia filosófica e filosofia da história é admitida e conhecida, chega-se, primeiro, a questão das consequências disso para a antropologia filosófica. E, segundo, a questão de se essa oposição é eliminável. O que anima tanto a tentativa de compreender uma vez mais a antropologia filosófica como um momento da filosofia da história, como também a tentativa de compreender a filosofia da história como um momento da antropologia filosófica. No entanto, as tentativas de eliminar o seu contrário dificilmente tem êxito em sua totalidade, deixando a questão fundamentalmente urgente de saber se a antropologia filosófica ou a filosofia da história tem razão (MARQUARD, 2007).

Karl Löwith nas obras De Hegel a Nietzsche e em El sentido de la historia busca compreender se o Ser e o sentido da história são determinados pela própria história ou, em caso contrário, por qual elemento eles seriam determinados. Segundo Luis Villanueva, trata-se de uma questão fundamental:

É uma questão que implica compreender se o movimento da história humana significa progresso, avanço e até redenção social, e a reconciliação da razão com a 
realidade ou se é uma navegação indefinida, contingente, aberta em seus fins, ainda que não em seus meios, se se quer ser eficaz. A questão conduz ao interminável debate de se haveria leis na história ou não, se a governam causas ou fins, se condicionamentos ou projetos, estruturas ou ações, se evoluções ou revoluções, no fundo, se se poderia falar com sentido de um fim da história ou não. Assim, as práticas políticas e acadêmicas se reorganizavam de diversos modos a partir das diversas respostas intelectuais a essas questões cardeais (VILLANUEVA, 2007, p. $192)^{5}$.

Na obra El sentido de la historia compreende a noção de filosofia da história enquanto uma interpretação sistemática da história universal a partir do princípio de que os acontecimentos se unificam e se dirigem a um significado fundamental. Nesse sentido, essa se vincula à teologia da história e a seu conceito de história como história da perfeição e da salvação. A filosofia da história se originaria no judaísmo e no cristianismo, na crença da perfeição e terminaria com a secularização de sua característica escatológica. Essa noção de finalidade é uma característica moderna, pois em momentos anteriores, questões como o problema do sofrimento eram abordadas com o mito de Prometeu e com a fé em Cristo, o primeiro um rebelde, o segundo um servidor, "nem a antiguidade, nem o cristianismo pretenderam iludir-se com a ideia de que a história pode ser concebida como uma evolução progressiva que elimine o problema do mal" (LÖWITH, 1958, p. 13) .

As especulações dos antigos gregos eram moderadas de forma que não pretendiam nem dar um sentido ao mundo, nem descobrir seu fim último. Para os gregos, em sua interpretação do mundo e da vida, tudo se movia em repetições, de inverno e verão, de geração e morte. Essa compreensão era de uma dominação da racionalidade do cosmos, nesse sentido, não existia a possibilidade de significação universal de um acontecimento histórico. Dessa forma, o ser humano e seu destino na história eram entendidos como um lugar onde o homem dispunha de recursos para enfrentar as diferentes situações, mas, além disso, eles não iam. Para os gregos, portanto, uma filosofia da história seria um contrassenso (LÖWITH, 1958).

A história, para o judaísmo e para o cristianismo, era compreendida como a história da salvação. E, segundo Löwith, a existência da filosofia da história e a busca por sua significação devem-se à história da salvação que se origina na crença de um fim último. A história política na era cristã também esteve sob a influência e o procedimento desse fim teológico. A concepção de messianismo e a significação permanente de tais secularizações, por exemplo, se funda na convicção religiosa de que o mundo precisa ser salvo e regenerado, pois se encontra em perigo (LÖWITH, 1958).

A filosofia e a teologia possuem uma posição distinta das demais 
ciências, pois abordam questões que não podem ser resolvidas a partir de conhecimentos empíricos, e esse horizonte foi estabelecido pela história. Mas, esse perguntar-se sobre o significado último da história relaciona-se com elementos da esperança e da crença. Já em relação à estrutura formal do significado da história, temos que essa requer sentido quando implica algum fim transcendente, além dos fatos reais. Assim, como a história é movimento temporal, seu objeto é uma meta e os fatos isolados não são em si mesmos significativos. Dessa forma, afirmar o significado de acontecimentos históricos somente é possível quando uma noção de fim se faz presente. Ou seja, a pretensão de finalidade histórica implica um objeto final que é transcendente aos acontecimentos em si (LÖWITH, 1958).

Temos um deslocamento da significação clássica de história que se ocupava dos acontecimentos passados e presentes. Os gregos compreendiam que os acontecimentos históricos tendiam as mesmas características dos acontecimentos passados, não pensavam nas possibilidades que o futuro encerrava. Ao passo que na modernidade o horizonte temporal de um objeto final é um futuro escatológico e esse futuro existe enquanto expectativa e esperança. É uma visão, a cristã e a moderna, que se referem a acontecimentos por vir (LÖWITH, 1958).

Essa escatologia, própria do judaísmo e cristianismo, não depende de uma lei natural da história pragmática e sim das esperanças e crenças humanas. O sentimento lógico frente ao futuro é de indecisão, pois é impossível calculá-lo teoricamente. A razão fundamental para que o futuro permaneça obscuro é a ausência dos pressupostos religiosos que tornavam o futuro inteligível para os antigos. Para os antigos, gregos e romanos, o futuro era pré-determinado, assim tomavam suas decisões depois de consultar 0 destino, ao passo que o homem moderno não acredita em guia algum, imagina que pode prever o futuro por si mesmo. Na modernidade, portanto, o futuro não pode ser investigado e conhecido como um fato, pois as crenças cristã e judaica desnaturalizaram o significado clássico de história (LÖWITH, 1958).

O futuro é o foco da história, mas sempre que a verdade esteja na fundação religiosa do ocidente cristão, cuja consciência histórica está determinada por uma situação escatológica. A significação dessa visão de um fim último fornece um esquema de ordem e de significações progressivas, que superou o esquema da antiguidade. Também delimitou o processo da história como um fim, articulando-o e provendo-o com um objetivo final. Nesse sentido, a história se tornou universal, visto que, é o que possibilita unidade a história do mundo, dirigindo-a a seu fim último: 
Nós, os homens do presente, interessados na unidade da História Universal, de seu processo até um fim último, ou, pelo menos, até um mundo melhor, nos encontramos, todavia, na linha do monoteísmo profético e messiânico, somos judeus e cristãos, não obstante o pouco que podemos pensar de nós mesmos em tais termos. Mas ao lado dessa tradição predominante somos também herdeiros da sabedoria clássica. Estamos na linha do politeísmo clássico quando nos interessamos pela pluralidade das diversas culturas e exploramos com curiosidade ilimitada a totalidade do mundo natural e histórico, guiados somente por um conhecimento desinteressado, sem preocupação alguma com a redenção (LÖWITH, 1958, p. 35).

Dessa forma, não pertencemos nem à antiguidade clássica, nem ao judaísmo e cristianismo, pertencemos à modernidade. $\mathrm{E}$ a modernidade elabora uma filosofia da história na qual seculariza os princípios teológicos aplicando-os a um número crescente de fatos empíricos.

Para Villanueva, três possibilidades se realizaram a partir dessa situação esboçada. A primeira delas é que alguns seguem obstinadamente em busca da reconciliação entre razão e realidade, lutando de formas variadas pela constituição de uma sociedade boa, por uma economia justa, por uma política pública, por um Estado universal, por uma sociedade fundada sobre princípios racionais. A segunda delas é daqueles que abandonaram a busca pela reconciliação, ou que reelaboraram os conceitos de racionalidade e de realidade, diminuindo sua denotação, tornando-a mais manipulável pelo uso das ciências e tecnologias sociais. E a terceira é daqueles da gramática pósmoderna, na qual a tentativa de reconciliação entre razão e realidade, e a tentativa de conciliação da realidade social é compreendida como um falso problema, não solucionável e ilusório, além de perigos por suas características autodestrutivas (VILLANUEVA, 2007).

Essa discussão em torno da metafísica tradicional, da ciência e tecnologia, da antropologia filosófica e da filosofia da história fundamenta o desenvolvimento histórico conceitual de emancipação. No desenvolvimento histórico conceitual dessa noção encontramos em Kant, que conhecia o significado jurídico romano dessa noção, a definição do esclarecimento não como emancipação, mas como:

[...] a saída do ser humano de sua menoridade, menoridade essa na qual ele se inseriu por sua própria culpa. Menoridade é a incapacidade de se servir de seu próprio entendimento sem a condução de outrem. É-se culpado por tal menoridade, se a causa da mesma não se encontra na falta de entendimento, mas na falta de resolução e de coragem para se servir de seu próprio entendimento sem a condução de outrem. Sapere aude! Tenha a coragem de te servir de teu próprio entendimento! - este é, portanto, o lema do esclarecimento (KANT, 2011, p. 23-24). 
O esclarecimento, entendido como estímulo e realização da maioridade, se estende assim ao longo de um período temporal que vai para além do ato jurídico unilateral concreto da emancipação.

Segundo Koselleck, Kant pode prescindir do termo emancipação a partir da afirmação de que os homens, de acordo com o direito consuetudinário, preferem, às vezes, seguir na menoridade por toda a vida:

\begin{abstract}
A preguiça e a covardia são as causas pelas quais uma parte tão grande dos seres humanos ainda permanece de bom grado menor a vida inteira, mesmo depois de a natureza tê-los livrado há muito tempo de uma condução alheia (naturaliter majorennes); e é por isso que é tão fácil aos outros arvorarem-se seus tutores. É tão cômodo ser menor (KANT, 2011, p. 24).
\end{abstract}

O que não significa que os seres humanos sejam incapazes de se liberarem dessa menoridade que quase se naturalizou. Para se esclarecer, segundo Kant, é necessário o uso próprio do entendimento e a liberdade de fazer o uso público da razão, "o uso público de sua razão precisa ser livre a todo o momento e só ele pode concretizar o esclarecimento entres os seres humanos" (KANT, 2011, p. 27).

Quanto às tentativas de seguir na menoridade, por causa da preguiça e da covardia, Kant é categórico ao afirmar que:

\footnotetext{
Um ser humano pode perfeitamente postergar o esclarecimento para sua pessoa e, por conseguinte, enquanto isso, também pode postergar, apenas por algum tempo, o que the cabe saber; entretanto, renunciar a ela, seja para sua pessoa, seja, com ainda maior razão, para a posteridade, significa violar e pisotear os sagrados direitos da humanidade (KANT, 2011, p. 32).
}

A máxima kantiana para o esclarecimento é "raciocinai, tanto quanto quiserdes e sobre o que quiserdes; apenas obedecei!" (KANT, 2011, p. 35).

A conversão da maioridade natural num imperativo moral e político que, possuindo um componente natural, é também mais que natureza, constitui um uso linguístico mais exato e mais eficaz que a metáfora ainda vinculada à emancipação jurídica. A maioridade, que por natureza se produz a cada nova geração, se converteu numa perspectiva histórica de futuro de uma humanidade que politicamente se governaria a si mesma. Em parte realidade, em parte fim, desse modo se descreveu como um acontecimento processual para aquilo que, pouco depois, se utilizou a expressão emancipação (KOSELLECK, 2012).

O alemão Georg Forster ${ }^{7}$ foi o primeiro escritor em Paris, durante a Revolução Francesa, a utilizar à filosofia kantiana sob o novo conceito de emancipação, que começava a ser discutido no espaço público francês. Com a 
expressão do conceito emancipação, em alemão - emancipieren -, se conectou com o sentido que tinha a palavra nos países vizinhos ocidentais. Foi concebida reflexivamente - emancipiert ou Selbstbefreiung -, como autoliberação, como autoemancipação das cadeias da tradição, como uma reivindicação normativa que devia legalizar-se mediante uma disposição legal estatal (KOSELLECK, 2012).

A vantagem do novo conceito de emancipação tal e como se utilizava, geralmente em torno do início do século XIX, consistia não só em indicar a recorrente maioridade natural das sucessivas gerações, mas também em se referir ao ato jurídico da liberação que se torna real mediante a autoliberação. Nessa equação, entre as premissas naturais, a autodeterminação individual e a normalização jurídica, adquiriu sua nova qualidade histórica. $O$ conceito podia ser interpretado, simultaneamente, em sentido normativo, em sentido autorreflexivo e a partir da perspectiva histórica. Sua temporalização tinha um componente constitutivo gerador de direito processual (KOSELLECK, 2012).

Para Koselleck, a emancipação se converteu no caso genuíno de um conceito processual da filosofia da história, um conceito que, sobretudo na primeira metade do século XIX, reuniu a força de um conceito guia. A emancipação se tornou um conceito que implica na eliminação da desigualdade jurídica, social, política e econômica. Desse modo, a expressão se converteu, em todos os casos, num conceito que exigia, fundamentalmente, a eliminação do domínio econômico. O conceito de emancipação se converteu no sistematizador mais lúcido de uma filosofia da história emancipadora. Ao se tornar polivalente, a expressão perdeu sua validez lógica, pôde assumir conteúdos políticos que diferiam completamente entre si, sem perder, com isso, sua razoabilidade geral. Adquiriu a condição e a evidência de um termo chave, uma palavra que pressupunha e evocava um consenso mínimo sobre a igualdade de direitos de todas as pessoas (KOSELLECK, 2012).

\section{Considerações finais}

$\mathrm{Na}$ contextualização dos elementos que compõem o problema da emancipação partimos da metodologia histórico conceitual, mostrando a origem e o desenvolvimento da noção de emancipação e indicando alguns momentos em que novos significados ou sentidos foram incorporados a esse conceito. Destarte, o humanismo e o lluminismo, a filosofia da história, a antropologia filosófica, a metafísica e ciência e a tecnologia fundamentam as discussões em torno do conceito de emancipação. 
O humanismo em seu desenvolvimento greco-romano e o humanismo cívico, enquanto movimento filosófico e literário que surgiu na Itália, que se encontram na origem da cultura moderna, influenciou a compreensão do conceito de emancipação. Tomaram como fundamento a natureza humana, exaltaram a liberdade e a dignidade do homem, exploraram os limites e os interesses humanos e reconheceram o valor humano em sua completude e igualdade. Ou seja, influenciaram fazendo uma defesa da dignidade humana através de um pensamento emancipador, repudiando todas as formas de violência e desenvolvendo uma consciência histórica de verdade.

O lluminismo formula a questão da liberação completa e definitiva dos seres humanos do domínio de outros seres humanos. Neste momento, também, apareceu a utilização do uso verbal reflexivo dessa noção, emanciparse, denotando a possibilidade de autoemancipação. Diante das mudanças ocorridas na Europa no século XVIII e com o lluminismo enquanto um programa teórico e pedagógico que identificava na razão a única instância normativa promotora do avanço da humanidade através de um projeto de crítica e de uma noção de progresso, que acabou impulsionando estas mudanças. Com as concepções de unidade do mundo, de caráter histórico e filosófico, comprometidas com o progresso, compreendem os conflitos como categorias da história com a possibilidade de superação e de emancipação ou autoemancipação.

Nessa análise do desenvolvimento e desdobramentos conceito de emancipação, encontra-se metafísica moderna e sua concepção de colocar em evidência a consciência de si autônoma. A filosofia da história e a antropologia filosófica com suas abordagens do mundo da vida e das possibilidades de livre desenvolvimento humano. A filosofia da história enquanto uma filosofia do destino do homem desenvolvida mediante uma teoria da liberdade como sua finalidade e mediante uma teoria do mundo histórico como mediação progressiva desta finalidade. E a ciência e tecnologia em seu desenvolvimento metodológico fundamentado numa racionalidade de meios e fins, em termos de funcionalidade e de eficiência, que se liga à noção de emancipação de formas diversas, positivas, como sinônimo de liberdade e negativas desta, enquanto forma de controle e domínio, como forma de não emancipação.

\section{Referências}

BOMBASSARO, Luiz Carlos; PAVIANI, Jayme; ZUGNO, Paulo Luiz (Orgs.). As fontes do humanismo latino: Da Antiguidade à Renascença. Porto Alegre: 
Edipucrs. 2003.

BULLOCK, Alan. La tradicion Humanista em Ocidente. Trad. Enrique Fernández-Barros. Madrid: Alianza Editorial. 1985.

CASSIRER, Ernest. A filosofia do Iluminismo. $3^{\text {a }}$ Ed. Trad. Álvaro Cabral. Campinas: Editora da Unicamp. 1997.

ELIAS, Norbert. O processo civilizador. Trad. Ruy Jungman. Rio de Janeiro: Jorge Zahar Editor. 1990. Vol. 1 Uma História dos Costumes, Vol. 2 Formação do Estado e Civilização.

FOUREZ, Gérard. A construção das ciências: introdução à filosofia e à ética das ciências. Trad. Luiz Paulo Rouanet. São Paulo: Unesp. 1995.

GALIMBERTI, Umberto. Psiche e techne: o homem na idade da técnica. Trad. José Maria de Almeida. São Paulo: Paulus. 2006.

HABERMAS, Jürgen. Perfiles filosófico-políticos. Trad. Manuel Jiménez Redondo. Madrid: Taurus. 1975.

KANT, Immanuel. Resposta à pergunta: que é o esclarecimento? In: O que é Esclarecimento? Trad. Paulo Cesar Gil Ferreira. Rio de Janeiro: Ed. Viaverita. 2011.

KOSELLECK, Reinhart. Historias de conceptos: Estudios sobre semántica y pragmática del lenguaje político y social. Madrid: Editorial Trotta. 2012.

Crítica e crise: uma introdução à patogênese do mundo burguês. Trad. Luciana Villas-Boas Castelo-Branco. Rio de Janeiro: EDUERJ: Contraponto. 1999.

LÖWITH, Karl. El sentido de la história: implicaciones teológicas de la filosofia de la historia. Trad. Justo Fernandez Bujan. Madrid: Ed. Aguilar. 1958.

. De Hegel a Nietzsche: a ruptura revolucionária no pensamento do

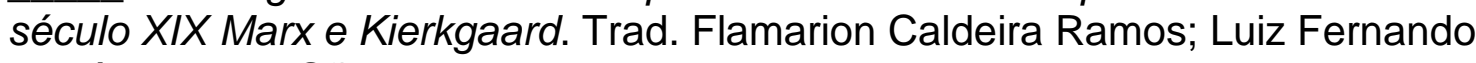
Barrére Martin. São Paulo: Ed. Unesp. 2014. 
MARCUSE, Herbert. A ideologia da sociedade industrial. Trad. Giasone Rebuá. Rio de Janeiro: Zahar. 1967.

MARQUARD, Odo. Las dificuldades con la filosofía de la historia ensayos. Trad. Enrique Ocaña. Valencia: Ed. Pre-Textos. 2007.

PICO DELLA MIRANDOLA, Giovanni. Discurso sobre a dignidade do homem. 6a Ed. Trad. Maria de Lurdes Sirgado Ganho. Lisboa: Edições 70. 2011.

SCHULZ, Walter. EL Dios de la metafísica moderna. Trad. Filadelfo Linares. México: Fondo de Cultura Económica. 1961.

SLOTERDIJK, Peter. Regras para o parque humano: uma resposta à carta de Heidegger sobre o humanismo. Trad. José Oscar de Almeida Marques. São Paulo: Estação Liberdade. 2000.

VILLANUEVA, Luis F. Aguilar. Entre el recuerdo y el olvido de los maestros: la exigencia de pensar la sociedade. In LÖWITH, Karl. Max Weber y Karl Marx. Trad. Cecilia Abdo Ferez. Barcelona: Ed. Gedisa. 2007.

\footnotetext{
${ }^{1}$ Defendida junto ao Programa Integrado de Pós-Graduação em Filosofia - PIPGF/UFPBUFPE-UFRN sob a orientação do prof. Dr. Edmilson Alves de Azevêdo com bolsa da CAPES.

${ }^{2}$ Todas as citações referentes a KOSELLECK, 2012 são traduções nossa.

${ }^{3}$ Inicia com Francesco Petrarca (1304-1374) na Itália e se dissemina pela Europa. Destacamos os seguintes autores em seus países: Itália, Leonardo Bruni (1374-1444), Lorenzo Valla (14071457), Leon Batista Alberti (1404-1472), Giovanni Pico Della Mirandola (1463-1494). França: Michel Montaigne (1533-1592). Alemanha: Rodolfo Agrícula (1442-1485).

${ }^{4}$ Todas as citações referentes à MARQUARD, 2007 são traduções nossas.

${ }^{5}$ Todas as citações referentes a VILLANUEVA, 2007 são traduções nossas.

${ }^{6}$ Todas as citações referentes a LÖWITH, 1958 são traduções nossas.

7 Forster (1754-1794) se manifestou de forma entusiasta a favor da revolução, defendeu, inclusive, a anexação à França dos territórios da margem esquerda do rio Reno. E, quando a cidade de Mainz foi reconquistada pela Prússia em 1793, não pôde mais regressar à Alemanha. Morreu em Paris em 1794 e foi depreciado na Alemanha por ter feito a defesa dos jacobinos.
} 